\title{
Genetic resources are the base for improving the assortment of sweet cherry and large fruit cherry plum
}

\author{
Valentina Gorina*, Lyubov Lukicheva, Aleksander Grigoriev, Leonid Chernen'ky, and \\ Janna Sokolovskaya
}

Federal State Funded Institution of Science "The Labor Red Banner Order Nikita Botanical Gardens National Scientific Center of the RAS", Nikita, 298648 Yalta, Russia

\begin{abstract}
The article presents the results of research on the genetic resources of sweet cherry and cherry plum in the Nikita Botanical Gardens - National Scientific Center. Cultivars which are the sources and donors of valuable economical and biological traits: late flowering, its duration, winter hardiness, drought resistance, large-fruited, very early and very late ripening and fruit taste, resistance to cracking in sweet cherry fruits have been identified. In order to create highly productive cultivars and breeding forms resistant to abiotic factors, sources of valuable traits from genetic collections were used, which significantly increased the efficiency of the breeding process. The gene pool includes more than 300 sweet cherry genotypes and more than 400 cherry plums. New promising cultivars have been identified. They allow updating the conveyor for obtaining highquality fruits in the southern zone of horticulture. Ten cultivars of sweet cherry: Uslada, Prizerka, Vesnyany Naspivy, Pikovaya Dama, Kutuzovka, Chernokrymka, Vitivnitsa, Znatnaya, Zarya Vostoka, Karadag and six cultivars of cherry plum: Andromeda, Desertnaya Rannaya, Obil'naya, Femida, Rumyanaya Zor'ka have been included in the State register of breeding in the Crimea and southern Russia. Four sweet cherry cultivars: Kudesnitsa, Ocharovanie, Triumf, Dolgojdannaya and one cherry plum cultivar: Feeriya, are undergoing a state test. Five new cultivars of sweet cherry and three cultivars of cherry plum, which surpass the zoned cultivars in a complex of valuable biological and economical characteristics, have been originated. The patents were received on these cultivars. A number of elite breeding forms of sweet cherry and cherry plum, which have a number of advantages over existing cultivars, have been originated.
\end{abstract}

\section{Introduction}

Fruits are important for keeping and strengthening of men`s health. They are valuable sources of sugars, acids, vitamins, biologically active substances, macro- and

\footnotetext{
*Corresponding author: valgorina@yandex.ru
} 
microelements, have a positive effect on the vital functions of the human body, improve well-being. To maintain a normal state, a person needs to consume up to $75 \mathrm{~kg}$ of fruits, including 7-8 kg of stone crops fruit [1]. In many countries all over the world and in Russia as well, people are not provided with the required amount of fruits. Therefore, the main task is to create and set up production of high yield cultivars of fruit crops, adapted to a wide range of unfavorable weather and pathogenic factors, characterized by high quality fruits and their balanced chemical composition. To increase the productivity and adaptability of fruit crops, an important element is the search for sources and donors with a complex of economically valuable traits combined in one genotype, their inclusion in the breeding process and the creation of new cultivars.

Sweet cherry fruits are very popular as well as cherry plum fruits have become recently. They are valued for their early ripening, rich chemical composition and high antioxidant activity $[2,3]$.

Sweet cherry fruits contain 10.9-21.6\% dry soluble substances, $8.12-15.48 \%$ sugars, $0.32-1.07 \%$ acids, $0.03-0.21 \%$ tannins and $2.53-11.96 \mathrm{mg} / 100 \mathrm{~g}$ ascorbic acid, as well as vitamins $\mathrm{B}_{1}, \mathrm{PP}$ and P-active substances [4]. Sweet cherry (Prunus avium L.) is cultivated in the world on an area of more than 443.7 thousand hectares [5]. The main regions growing sweet cherries and supplying their fruits to the world market are Asia $(40.9 \%$ of world production), Europe (40.4\%), and America (17.3\%). Africa (0.9\%) and Oceania $(0.6 \%)$ make a small contribution to world sweet cherry production. The largest area under sweet cherry plantations in 2019 was in Greece (16.1 thousand hectares), Chile (38.4 thousand hectares), Spain (27.5 thousand hectares), Iran (28.3 thousand hectares), Italy (29.2 thousand hectares), Syria (29.9 thousand hectares) and the USA (35.2 thousand hectares). According to 2016 data, the leading countries in the sweet cherry fruits production are Turkey (664.2 thousand tons), the USA (321.4 thousand tons), Iran (128.3 thousand tons) and Chile (233.9 thousand tons). A significant amount of fruits are harvested in Uzbekistan (175.8 thousand tons), Italy (98.6 thousand tons), Spain (118.4 thousand tons), Romania (39.1 thousand tons), Greece (81.6 thousand tons), Syria (66.0 thousand tons), Ukraine (68.6 thousand tons) and Poland (44.4 thousand tons/ha). In the Russian Federation, 10.0 thousand hectares under sweet cherry plantations, and in 201948.7 thousand tons of fruits were harvested, the yield was only 4.9 tons/ha [5].

At the end of the 19th century, sweet cherries assortment in the Crimea was represented mainly by local selected forms and a few cultivars from Turkey. At the beginning of the 20th century, thanks to the activities of the Nikita Botanical Gardens, the collections were supplemented with some European cultivars. Due to the introduction of foreign and native genotypes, the collection has been constantly increasing. In the early $30 \mathrm{~s}$, breeding work on the base of old local forms with the use of the best introduced cultivars was widely developed. As a result of the works carried out in the Nikita Botanical Gardens, sweet cherries were grown not only in the southern and foothill zones, but also in the steppe. Breeding and selection were developed by Ryabov I.N., Ryabova A.N., Voloshina A.A., Kryukova I.V., Orekhova V.P., Tarasyuk G.M., Lukicheva L.A. and Tarasova E.V. They had originated sweet cherry cultivars that were accepted not only in the Crimea, but also abroad. However, climate changes, an increase in harmful organisms and an increase in consumer demands require an improvement in the assortment of this crop.

Cherry plum belongs to the genus Prunus L. and includes a lot of species. It is widely cultivated all over the world. According to the data 2018, the area under the cherry plum crop was 2.6 million hectares. The main producing regions for this crop are Asia (60.4\% of world production), Europe (25.9\%), and America (10.5\%). Africa (2.9\%) and Oceania $(0.3 \%)$ make an insignificant contribution to the world production of plums and cherry plums. Commercial plantings of plum, including diploid species and cultivars, which cherry plum belongs to, are mainly concentrated in China. Their area in this country, according to 
2019 data, is slightly more than 2.1 million hectares. Large areas under plum plantations are in Serbia (72.3 thousand hectares), Romania (65.6 thousand hectares), Bosnia and Herzegovina (59.9 thousand hectares), Russia (41.4 thousand hectares), Iran (14.2 thousand hectares), India (31.4 thousand hectares), the USA (23.9 thousand hectares) and Turkey (21.0 thousand hectares). The main producer of plum fruits is China (7.0 million tons). Romania (692.7 thousand tons), Serbia (558.9 thousand tons), USA (340.0 thousand tons), Turkey (317.9 thousand tons), Chile (465.3 thousand tons), Iran (359.1 thousand tons), India (261.9 thousand tons), Spain (179.8 thousand tons), Italy (215.0 thousand tons), France (205.1 thousand tons), Ukraine (181.1 thousand tons) and Russia (174.0 thousand tons) are among the leading producers. The use of plum fruits in food and medicinal industries is associated with their valuable chemical composition. Depending on the cultivar and growing region, plum fruits contain 7-25\% sugars (including monosaccharides $3-12 \%$ ), $26 \%$ dry substances, up to $3 \%$ free acids, about $1 \%$ hemicelluloses and up to $2.5 \%$ pectin substances. The fruits also contain $350 \mathrm{mg} / 100 \mathrm{~g}$ tannins, $22 \mathrm{mg} / 100 \mathrm{~g}$ vitamin $\mathrm{C}$, $13.4 \mathrm{mg} / 100 \mathrm{~g}$ pyridoxine, up to $2.5 \mathrm{mg} / 100 \mathrm{~g}$ vitamin $B_{9}$ and up to $0.14 \mathrm{mg} / 100 \mathrm{~g}$ carotene, in terms of fresh weight. Macro- and microelements, such as potassium, calcium, magnesium, phosphorus, iron, sodium, manganese, cobalt and other substances are present in plum fruits [6].

In the middle of the 20th century, cherry plum (Prunus cerasifera Ehrh.) culture was initiated in some countries. Its plants enter the fruiting period early, unpretentiousness to growing conditions and are characterized with winter hardiness and regular high productivity [7]. Cherry plum proved to be the most adapted to various regions of cultivation and occupied an ecological niche less favorable for moisture-loving plums. This culture spread widely in the Crimea, first on the southern coast, then in the steppe and foothill zones. The cultivars of large-fruited cherry plum, created by Kostina K.F., and somewhat later by Eremin G.V., with the use of Chinese plum ( $P$. salicina Lindl.) cultivars and other introduced plum species, became especially popular. A commercial cherry plum assortment was formed and made it possible to introduce it in culture along with other stone fruit crops. The cultivars of the hybrid cherry plum were combined into a cultivated species, which was named Russian plum (P. rossica Erem.) [6]. In the Nikita Botanical Gardens, K.F. Kostina and O.A. Zabranskaya did a great job for establishing and studying its gene pool. A bit later these studies were continued by E.P. Shoferistov, A.M. Sholokhov, T.M. Savvina, G.A. Gorshkova, V.M. Gorina and N.G. Ageeva. However, it is necessary to enrich the cherry plum assortment with cultivars of very early and very late fruit ripening in combination with high quality of fruits and adaptive capacity of plants.

The aim of the presented research was a comprehensive study of the sweet cherry and cherry plum genetic resources in the Nikita Botanical Gardens, the selection of promising sources and donors of valuable for breeding features and improving the commercial assortment of these crops.

\section{Materials and methods}

The research was carried out in 2015-2020 in the Simferopol region (steppe Crimea), which is characterized by an arid climate, a moderately hot growing season and mild unstable winters. The average annual precipitation is $480 \mathrm{~mm}$ [8].

The research objects were sweet cherry $(P$. avium L.) and cherry plum $(P$. cerasifera subsp. Macrocarpa (Ehrh.) Erem. Et Garcov.) cultivars and forms, planted in 2011 according to the scheme $5 \times 4 \mathrm{~m}$, rootstocks were Magaleb cherry seedlings (for sweet cherry) and typical cherry plum seedlings (for large-fruited cherry plum). The studies included 100 cultivars and breeding forms of sweet cherry and 95 cherry plums. As a control, we used widely spread zoned cultivars of sweet cherry Zarya Vostoka and cherry 
plum Olen'ka. Phenological observations on plants, assessment of cultivars and breeding forms, hybridization and selection of promosing genotypes were carried out according to the common methods $[9,10]$. Winter hardiness in the field was assessed according to the generally accepted method [11]. The drought resistance in the studied plants was determined with the method by Lishchuk A.I. and Pilkevich R.A. [12]. Anatomical and morphological analysis of the generative buds was carried out according to the well-known method by A.M. Sholokhov [13]. Statistical analyses of the experimental data was carried out according to recommendations [14] using Microsoft Excel 2007 and Statistica 10 programs.

\section{Results and discussion}

In the Nikita Botanical Gardens (NBG) there are great collections of stone fruit crops, including 11 species from the genus Prunus L.: P. cerasus L., P. avium L., P. domestica L., P. armeniaca L., P. salicina Lindl., P. cerasifera Ehrh., P. dasycarpa Ehrh., P. brigantiaca Vill., P. spinosa L., P. rossica Erem. and P. simonii Carr. [15]. The genotypes of these species and breeding forms created as a result of intercultivar and interspecific hybridization have a wide range of different characteristics: the terms of flowering and fruit ripening, frost resistance of generative buds, winter hardiness and drought resistance of plants, resistance to various harmful pathogens, commercial qualities of fruits and other indicators. Collections are the basis for improving the assortment under a pressure of a changing environment [16-18]. As a result of many years of research, cultivars and forms that are the sources of valuable features for breeding have been identified.

The gene pool collection of sweet cherry (P. avium L.) includes more than 200 genotypes from 19 countries. Cultivars and forms belong to various ecological and geographical groups: Western European (14.8\%), American (8.5\%), Caucasian (1.8\%), Moldovan (1.8\%), Crimean (27.4\%), Central Ukrainian (25.6\%), northern (17.5\%). According to the country of origin cultivars are: from Europe $-16.25 \%$, from the USA and Canada $-7.4 \%$, from the former CIS countries - 76.35\%. Furthermore, there are 140 elite forms and 180 hybrid seedlings of sweet cherry.

In the process of introduction and breeding, unique collections of cultivars and breeding forms of various plum species were collected: the European plum ( $P$. domestica L.), Chinese plum ( $P$. salicina Lindl.), cherry ( $P$. cerasifera Erhr.) and others. At present, the gene pool of the cherry plum in the Nikita Botanical Gardens contains more than 400 genotypes (including 168 cultivars) and more than 200 hybrid seedlings. It contains cultivars belonging to different groups by their origin: typical cherry plum, armenian, georgian, iranian, tauride, red-leaved and hybrid [6]. Each group of cultivars is characterized by certain featuress that are valuable for breeding. This extensive collection enables breeding of plum crops in various directions.

For sweet cherry breeding programs, genotypes characterized by such valuable features as large fruit size, yield, high commercial and taste qualities of fruits, transportability, winter and drought resistance, resistance to major harmful diseases, and resistance to fruit cracking are of great interest $[19,20]$.

As a result of many years of research, sources and donors of characteristics useful for breeding programs have been identified in sweet cherries (Table 1). 
Table 1. Donors and sources of economic and biological characteristics of sweet cherries

\begin{tabular}{|l|l|}
\hline \multicolumn{1}{|c|}{ Features } & \multicolumn{1}{c|}{ Cultivars, forms } \\
\hline Late flowering & $\begin{array}{l}\text { Balzams, Meelika, Vidzemes Sartveidsis, Amazonka, AM-28-6-1, Bigarro Almad } \\
\text { Av Goldred, Jemchujnaya, Recordistka, Drogans Gelbe }\end{array}$ \\
\hline Early fruit ripening & $\begin{array}{l}\text { Uslada, Vesniyni Naspevy, Rubinovaya Rannyaya, Patriotka Kryma, Dagestanka, } \\
\text { Д-48-52, Bigarreu Burlat, Miinhebergi }\end{array}$ \\
\hline Late fruit ripening & Jemchujnaya, Skeena, Rube, Dolgojdannaya, Triumf, Recordistka, Drogans Gelbe \\
\hline Large fruits & $\begin{array}{l}\text { Mechta, Prestijnaya, Krupnoplodnaya, Vasilisa, Stella, Kutuzovka, Znatnaya, } \\
\text { Anons, Kolhoznitsa, Bigarreu Starking }\end{array}$ \\
\hline $\begin{array}{l}\text { Commercial } \\
\text { qualities of fruits }\end{array}$ & $\begin{array}{l}\text { Skazka, Chernokrymka, Kutuzovka, Uslada, Melitopol'skaya Chernaya, Vasilisa, } \\
\text { Hedelfingen, Rube, Annushka, Anons, Pikovaya Dama, Zabava, Mechta, Temp, } \\
\text { Francis }\end{array}$ \\
\hline $\begin{array}{l}\text { Resistance to fruit } \\
\text { cracking }\end{array}$ & $\begin{array}{l}\text { Znatnaya, Zagadka, Kutuzovka, Karadag, Zemfira, Rube, Vineland, Vittovia, } \\
\text { Elfrida }\end{array}$ \\
\hline Self-fertility & Lapins, Skeena, Stella, Sweetheart \\
\hline $\begin{array}{l}\text { Resistance to fungi, } \\
\text { pathogens }\end{array}$ & \multicolumn{1}{|c|}{$\begin{array}{l}\text { Meelika, Szoniolai 215, Tommu, Bryanok, Д-24-44c, Orlovskaya Yantarnaya } \\
\text { mut.768, Temp, Zagadka, Rubinovaya Rannyaya }\end{array}$} \\
\hline Winter hardiness & $\begin{array}{l}\text { Zarya Vostoka, Drogans Gelbe, Donchanka, Chernokrymka, Valeriyi Chkalov, } \\
\text { Donetskiy Ugolek, Zolotaya Loshytskaya, Severnaya, Bryanok, Bigarro } \\
\text { Oratovskogo, Д-48-52, Donetskaya Krasavitsa, Bada }\end{array}$ \\
\hline $\begin{array}{l}\text { Kassins Frune, Stella, Anons, Alina, Valeriya, Valeriyi Chkalov, Krymskaya Noch, } \\
\text { Mechta, Severnaya, Yantarnaya }\end{array}$ \\
\hline
\end{tabular}

Of particular importance are cultivars with high adaptability, since the climatic conditions of the growing region limit the cultivation of certain crops (cultivars) in the steppe zone of the Crimea [21]. Stress factors that negatively affect the crops grown are low freezing temperatures during the dormancy period, as well as return frosts in spring, when the plants are already developing. Cultivars with slower plant development are of great interest. For the period from 2015 to 2020 , the most critical year was 2015, when in January the temperature dropped to $-26.0^{\circ} \mathrm{C}$ that resulted in significant damage of the generative organs. The death of generative buds in sweet cherry plants ranged from $22 \%$ (cultivar Drogans Gelbe) to $100 \%$ (cultivar Zagadka), on average $63.6 \% \pm 4.3$ with a coefficient of variation (V) of $36.4 \%$. The cultivars Zarya Vostoka, Drogans Gelbe, Patriotka Kryma, Krymskaya Noch, Znatnaya, Sovremennitsa, Vitivnitsa, Severnaya, Tommu, Jemchujnaya, Zolotaya Loshitskaya, Meelika, Balzams, Elfrida, etc demonstrated a high level of winter hardiness components. Among the promising breeding forms, the most resistant ones were selected: Orlovskaya Yantarnaya mut. 768, 387, 828, 964, 270a, 275, 453, 471, 478, 537, 602, 297, 300, 305, 460, 293.

Significant return frosts were recorded in 2016, 2017, 2019 and 2020. Under these conditions, the most resistant (plastic) sweet cherry cultivars were Drogans Gelbe, Rannyaya Rozovaya, Znatnaya, Vitivnitsa, Syubarovskaya, Severnaya, Annushka, AM-286-1, Nord, Vidzemes Sartveidsis and the breeding forms Orlovskaya Yantarnaya mut. 768, 291, 294, 749, 764, 777, 980, 984 and others.

In recent years, summer droughts have become more frequent in the Crimea that has a negative effect on the yield formation in fruit crops. Therefore, one of the tasks in originating new cultivars is to identify and select sources and donors of resistance to high temperatures. The cultivars characterized by high drought resistance were included in the characteristic collection of sweet cherries: Kassins Fruhe, Anons, Alina, Valeriyi Chkalov, Valeria, Krymskaya Noch, Mechta, Karadag, Triumf, Patriotka Kryma, Severnaya, Yantarnaya, Vitivnitsa, Uslada. Genotypes with a high degree of adaptability and the ability to carry out physiological processes under the water stress conditions have been selected: $297,300,343,387,460,537,355,601,602$ [22].

The resistance to sweet cherry fruits cracking after rain is a varietal feature and it is due to the differences in the physical and, possibly, chemical properties of the cell wall, as well 
as differences in the mechanical properties of the skin [23]. The cultivars with increased resistance have been identified - Znatnaya, Zagadka, Kutuzovka, Karadag, Zemfira, Rube, Vineland, Vittovia, Elfrida.

To actualize breeding programs for the creation of new cherry plum cultivars, sources and donors of such useful features as large fruits, high taste and commercial qualities of fruits, high winter and frost resistance of plants, their drought resistance and tolerance to major pathogens are needed [24].

As a result of many years of research in the collection of large fruit cherry plum ( $P$. cerasifera subsp. macrocarpa (Ehrh.) Erem. Et Garcov.), sources of valuable breeding features have been identified (Table 2).

Table 2. Sources of economically valuable features for cherry plum breeding.

\begin{tabular}{|l|l|}
\hline \multicolumn{1}{|c|}{ Features } & \multicolumn{1}{c|}{ Cultivars } \\
\hline $\begin{array}{l}\text { Undersized, compact } \\
\text { crown }\end{array}$ & $\begin{array}{l}\text { Duimovochka, Volshebnitsa, Izyumnaya, Eliasova, Zarya Kubani, Yaltinskaya } \\
\text { Krasavitsa, Berbank, Alenushka }\end{array}$ \\
\hline Late flowering & $\begin{array}{l}\text { Rumyanaya Zor'ka, Alupka, Rubinovaya, Inostranka, Mashen'ka, Krymskaya } \\
\text { Smuglyanka, Puteshestvennitsa, Duimovochka, Desertnaya, Nagrada, Pisarda } \\
\text { Krupnoplodnaya }\end{array}$ \\
\hline Early fruit ripening & Kiziltashskaya Rannyaya, Subhi Rannyaya, Evgeniya, Kurortnaya \\
\hline High fruit quality & $\begin{array}{l}\text { Obil'naya, Desertnaya, Olen'ka, Desertnaya Rannyaya, Femida, Andromeda, } \\
\text { Rumyanaya Zor'ka, Kubanskaya Kometa, Feeriya, Volshebnitsa, Kometa Nikitskaya, } \\
\text { Alupka, Kassiya, Fioletovaya Desertnaya }\end{array}$ \\
\hline Productivity & $\begin{array}{l}\text { Ashtarakskaya №2, Bordovaya, Izyumnaya, Kassiya, Krasnomyasaya, } \\
\text { Kiziltashskaya Rannyaya, Lusha Vishnevaya, Lusha Jeltaya, Mashen'ka, Obil'naya, } \\
\text { Obil'naya Novaya, Puteshestvennitsa, Rumyanaya Zor'ka, Rubinovaya, Subhi } \\
\text { Rannyaya, Serenada, Uyutnaya }\end{array}$ \\
\hline Winter hardiness & $\begin{array}{l}\text { Kometa Rannyaya, Krymskaya Smuglyanka, Nagrada, Nikitskaya Jeltaya, Olen'ka, } \\
\text { Ostryakovskaya, Puteshestvennitsa, Rapsodiya, Rumyanaya Zor'ka, Subhi Rannyaya }\end{array}$ \\
\hline Drought resistance & $\begin{array}{l}\text { Bertavrikson, Granit, Evgeniya, Jeltaya Pozdnyaya, Zemlyanichnaya, Kassiya, } \\
\text { Kommunarka, Lusha Tavricheskaya, Obil'naya Novaya, Pionerka }\end{array}$ \\
\hline
\end{tabular}

It is known that cherry plum plants are generally characterized by a short and less deep dormancy period. During biological dormancy, the generative buds of cherry plum can withstand a drop in air temperature to $-25^{\circ} \mathrm{C}$, and in some cultivars even to $-30^{\circ} \mathrm{C}$ [25]. However, in the Crimea, frequent thaws in winter are favourable for the early break of deep dormancy in cherry plum plants and return frosts damage the generative sphere that negatively affects the yield formation. It is necessary to select genotypes with slow development of plants and their late flowering. Late flowering genotypes $8 / 18,8 / 26,8 / 27$, $8 / 28,8 / 29,8 / 30,9 / 2,9 / 7,9 / 20,9 / 21,9 / 22,9 / 26,12 / 19 a, 12 / 19 b, 12 / 22 a, 12 / 23 a, 12 / 26 a$, $12 / 26 \mathrm{~b}, 12 / 28,12 / 30,13 / 6,13 / 16,14 / 15,14 / 17,9-013,87-87,7673,5870,9-3 / 15,13-2 / 15$, 07-2-2010 were determined [26].

Despite the fact that cherry plum plants are more drought-resistant than the European plum, in the conditions of the Crimea, its plantations require irrigation. The study of this index and the selection of drought-resistant genotypes will make it possible to identify promising forms or create new cultivars for regions with low moisture supply in the Crimea and southern Russia. As a result of the research, drought-resistant cultivars and forms were selected: Pionerka, Zemlyanichnaya, Obil'naya, Femida, Vetryaz 2, Lyikhny, Chudesnaya, Jelannaya, Pisarda Krupnoplodnaya, 9/5, 9/8, 9/12, 9/26, 9/33, 10/3, 10/8, 10/13, 10/16, $10 / 22,10 / 31,11 / 3,11 / 10,11 / 20,11 / 24,11 / 30 \mathrm{a}, 12 / 28,13 / 6,13 / 22,14 / 4,15 / 30 \mathrm{a}, 16 / 26$ and others.

Most cherry plum cultivars are practically immune to monilial burn. In some years, its plants are affected by Clasterosporium carpophilum Aderh. Lev. Spots appear on the leaves, the tissues of which then darken and fall out. It resulted in deterioration of the leaf apparatus work and further decrease in plant productivity. It is known that these diseases weakly affect hybrids of georgian, armenian, iranian cherry plum cultivars. Russian plum 
cultivars: Kubanskaya Kometa, Puteshestvennitsa, Naidena and some others are resistant to a complex of plum diseases [6]. Because of the spread of pathogens affecting cherry plum, it is necessary to create cultivars that are more resistant to them, especially to Clasterosporium carpophilum Aderh. Lev. Cultivars and breeding forms that are less affected by this pathogen have been selected (Souvenir, Zurna, Evgeniya, Krymskaya Smuglyanka, Medovaya, Krymskaya Jeltaya Sladkaya, Mac Verne, Olen'ka, Symphoniya, Donchanka, Zemlyanichnaya and forms 17/14, 9/7, 9 / 21, 11/8, 13-113, 93-44, 91-268, etc.). Based on the research results, new promising breeding forms were identified [27].

A brief description of new cherry plum promising forms is presented in Table 3 .

Table 3. Economical and biological characteristics of cherry plum, 2015-2020.

\begin{tabular}{|c|c|c|c|c|c|}
\hline \multirow{2}{*}{$\begin{array}{l}\text { Breeding } \\
\text { form }\end{array}$} & \multicolumn{2}{|c|}{ Phenological observations } & \multirow{2}{*}{$\begin{array}{c}\text { Fruit } \\
\text { mass, g }\end{array}$} & \multirow{2}{*}{$\begin{array}{l}\text { Fruit skin } \\
\text { colour }\end{array}$} & \multirow{2}{*}{$\begin{array}{l}\text { Damages with } \\
\text { return frosts, \% }\end{array}$} \\
\hline & $\begin{array}{l}\text { Beginning of } \\
\text { flowering }\end{array}$ & $\begin{array}{l}\text { Beginning of } \\
\text { fruit ripening }\end{array}$ & & & \\
\hline Olen'ka (к) & $13.04 \pm 5.0$ & $27.07 \pm 8.0$ & $27 \pm 3.3$ & Dark red & $70 \pm 7.5$ \\
\hline $11 / 8$ & $07.04 \pm 2.0$ & $29.06 \pm 4.0$ & $22 \pm 6.0$ & Purple & $2 \pm 1.0$ \\
\hline $11 / 3$ & $17.04 \pm 6.0$ & $28.07 \pm 2.0$ & $20 \pm 2.5$ & Yellow & $95 \pm 5.0$ \\
\hline $11 / 26$ & $19.04 \pm 5.0$ & $30.07 \pm 3.0$ & $15 \pm 4.0$ & Yellow & $7 \pm 3.0$ \\
\hline $11 / 12$ & $15.04 \pm 10.0$ & $07.07 \pm 3.0$ & $25 \pm 4.0$ & Purple & $50 \pm 11.0$ \\
\hline $11 / 286$ & $07.04 \pm 2.0$ & $16.07 \pm 1.0$ & $24 \pm 3.0$ & Purple & $1 \pm 0.5$ \\
\hline 720 & $02.04 \pm 4.0$ & $01.07 \pm 3.0$ & $10 \pm 2.0$ & Maroon & $6 \pm 2.7$ \\
\hline 737 & $04.04 \pm 2.0$ & $19.06 \pm 4.0$ & $11 \pm 4.0$ & Yellow & $95 \pm 5.0$ \\
\hline $9-013$ & $20.04+5.0$ & $07.07 \pm 5.5$ & $32 \pm 6.0$ & Purple & $50+2.9$ \\
\hline $90-54$ & $07.04 \pm 2.0$ & $17.07 \pm 3.0$ & $20 \pm 3.0$ & Yellow & $10 \pm 2.5$ \\
\hline $8 / 26$ & $14.04 \pm 5.0$ & $15.07 \pm 3.0$ & - & - & $3+0.5$ \\
\hline $16 / 63$ & $18.04 \pm 3.0$ & $28.07 \pm 3.0$ & $10 \pm 0.5$ & Yellow & $80 \pm 4.7$ \\
\hline $8 / 27$ & $15.04 \pm 1.0$ & $16.08 \pm 1.0$ & $14 \pm 3.5$ & Dark purple & $70 \pm 7.4$ \\
\hline $15 / 27$ & $03.04 \pm 1.0$ & $12.07 \pm 5.0$ & $22 \pm 13$ & Burgundy & $2 \pm 0.5$ \\
\hline $9 / 26$ & $19.04 \pm 3.0$ & $03.07 \pm 2.0$ & $28 \pm 2.7$ & Yellow & $40 \pm 12.0$ \\
\hline $13 / 6$ & $18.04 \pm 3.0$ & $23.07 \pm 3.0$ & $23 \pm 2.0$ & Yellow & $90 \pm 4.6$ \\
\hline $9 / 14$ & $08.04 \pm 3.0$ & $10.07 \pm 3.0$ & $25 \pm 5.0$ & Burgundy & $3 \pm 1.5$ \\
\hline $9 / 15$ & $04.04 \pm 2.0$ & $15.07 \pm 5.0$ & $20 \pm 3.0$ & Burgundy & $3 \pm 1.0$ \\
\hline $9 / 7$ & $13.04 \pm 3.0$ & $10.07 \pm 8.0$ & $24 \pm 4.0$ & Purple & $92 \pm 2.4$ \\
\hline $9 / 27$ & $17.04 \pm 5.0$ & $26.07 \pm 2.5$ & $10 \pm 5.0$ & Carmine & $60 \pm 5.5$ \\
\hline $9 / 21$ & $14.04 \pm 3.0$ & $13.07 \pm 2.0$ & $28 \pm 3.4$ & Burgundy & $50 \pm 9.1$ \\
\hline $9 / 22$ & $13.04 \pm 2.0$ & $05.07 \pm 2.0$ & $22 \pm 5.1$ & Purple & $6 \pm 2.0$ \\
\hline $12 / 10 \sigma$ & $03.04 \pm 1.0$ & $16.07 \pm 2.0$ & $18 \pm 6.0$ & Yellow & $1 \pm 0.5$ \\
\hline $12 / 2$ & $03.04 \pm 2.0$ & $20.07 \pm 3.0$ & $21 \pm 6.0$ & Dark red & $10 \pm 1.7$ \\
\hline $12 / 26 a$ & $19.04+4.0$ & - & $25+5.0$ & Burgundy & $75 \pm 4.5$ \\
\hline $\mathrm{HCP}_{0,5}$ & 2.5 & 2.2 & 6.7 & - & 17.3 \\
\hline
\end{tabular}

Eight forms are characterized by a late flowering timing (17-20.04). Their plants begin to bloom 4-7 days later than the control cultivar Olen'ka. Among the selected forms, two (Pionerka 737 and Olen'ka St. op. 11/8) are characterized by early fruit ripening, and four (Olen'ka St. op. 11/26, Olen'ka St. op. 11/23, 16/63 (8/16) and Scarlet Flower of St. op. $8 / 27$ ) - by late fruit ripening. Three breeding forms had larger fruits (compared to the 
control cultivar): (Kubanskaya Kometa x Subhi Rannyaya) 9/26, St. op. 9/21 and 9-013. According to the frost resistance of generative buds 16 promising forms were selected. Under the pressure of low negative temperatures the death of their buds ranges from 1 to $50 \%$ that does not have a negative effect on the cherry plum plants productivity. According to the complex of valuable features, three forms have been identified: 9-013, (Kubanskaya Kometa x Subhi Rannyaya) 9/26 and St. op. 9/21.

The studies of genetic resources made it possible to identify the most effective parental pairs for the creation of high quality adaptive and technological cultivars and forms for further breeding and intensive commercial horticulture. In the collections of sweet cherries and cherry plums, sources with a complex of high productivity, fruit quality and plant resistance to biotic and abiotic environmental factors have been identified.

Sweet cherry cultivars - complex sources of valuable features:

- late flowering, high winter hardiness: Znatnaya, Drogans Gelbe, AM-28-6-1, Jemchujnaya;

- late flowering, resistance to fruit cracking: Zagadka, Rube;

- winter hardiness, high market and taste qualities of fruits: Bada, Znatnaya, Zarya Vostoka.

- winter hardiness and drought resistance, commercial qualities of fruits: Uslada, Valeriyi Chkalov, Donetskaya Krasavitsa;

- early ripening, market and taste qualities of fruits: Uslada, Bigarreu Burlat;

- late ripening, high quality of fruits: Rube, Zarya Vostoka, Triumf;

- resistance to fruit cracking, high commercial and taste qualities of fruits: Znatnaya, Zagadka, Kutuzovka, Zemfira.

Complex sources for cherry plum:

- late flowering, late ripening, high market and taste of fruits, higher winter hardiness: Rumyanaya Zor'ka, Olen'ka;

- undersize growth, late flowering, late fruit ripening, high market and taste qualities of fruits: Volshebnitsa;

- high yield, large fruit, very early ripening and good taste of fruits: Subhi Rannyaya;

- early ripening, high market and taste qualities of fruits: Salgirskaya Rumyanaya;

- late ripening, good taste and universal use of fruits: Ashtarakskaya No. 2, Aromatnaya, Kometa Nikitskaya;

- high winter hardiness, high market and taste qualities of fruits: Kometa Rannyaya, Olen'ka, Nagrada, Subhi Rannyaya, Puteshestvennitsa;

- large fruit, late ripening of fruits, dark-red color of fruit skin and pulp, anthocyanin color of the leaves: Pisarda Krupnoplodnaya;

- late ripening, high commercial and taste qualities of fruits: Alupka, Kometa Nikitskaya, Rumyanaya Zor'ka.

- drought resistance, high market qualities of fruits: Zemlyanichnaya, Granite, Kassiya, Obil'naya Novaya.

As a result of the research, promising cultivars and breeding forms of sweet cherry and cherry plum were obtained. 10 cultivars of sweet cherry have been included in the State Register of selection achievements permitted for use in the zone of the Crimea and southern Russia: Uslada, Prizerka, Vesnyany Naspevy, Pikovaya Dama, Kutuzovka, Chernokrymka, Vitivnitsa, Znatnaya, Zarya Vostoka, Karadag and six cultivars of cherry plum: Andromeda, Dessertnaya Rannaya, Obil'naya, Femida, Rumyanaya Zor'ka, Olen'ka. Four sweet cherry cultivars are under the state testing: Kudesnitsa, Ocharovanie, Triumf, Dolgojdannaya and one cherry plum cultivar: Feeriya. 


\section{Conclusions}

The study of the genetic resources of sweet cherry and cherry-plum, concentrated in the Nikita Botanical Gardens, enabled identification of sources and donors of valuable features and create on their basis new cultivars adapted to the conditions of the Crimean steppe zone, with fruits of high taste qualities.

The result of breeding work is ten cultivars of sweet cherry and six cultivars of cherry plum, included in the Register of cultivars Breeding Achievements and recommended for wide commercial implementation in the Crimea and southern Russia. Five new cultivars of sweet cherry and three cultivars of cherry plum, which surpass the zoned cultivars in a complex of valuable biological and economical characteristics, have been originated. The patents were received on these cultivars.

\section{References}

1. V. L. Vitkovsky, Fruit plants of the world, 203 (2003)

2. Di Matteo, R. Russo, G. Graziani, A. Ritieni, C. Di Vaio, Characterization of autochthonous sweet cherry cultivars of southern Italy for fruit quality, bioactive compounds and antioxidant activity (2016)

3. L. San Martino, F. A. Manavella, D. A. Garcia, G. Salato, Acta Hortic, 795, 841 (2008) https://actahort.org/

4. N. I. Turovtsev, L. I. Taranenko, V. V., Pavlyuk, Harvest, 4, 272 (2004)

5. Food and Agriculture Organization of the United Nations (FAO) http://www.fao.org/

6. G. V. Eremin, Plum and cherry plum, 302 (AST, 2003)

7. G. V. Eremin, Cherry plum, 112 (Agropromizdat, 1989)

8. V. V. Antyufeyev, The reference book about climate of the Steppe department of Nikita Botanical Gardens, 88 (2002)

9. E. N. Sedov and T. P. Ogoltcova, Program and methods of variety research of fruit, berry and nut crops, 606 (1999)

10. E. N. Sedov and T. P. Ogoltcova, Programme and technique of breeding of fruit, berry and nut crops, 503 (1995)

11. E. A. Yablonskiy, Methodical recommendations for assessing the winter hardiness of stone fruit and nut crops, 26 (1984)

A. I. Lischuk, R. A. Pilkevich, Collection of scientific papers of GNBS, 118, 113 (1999)

A. M. Sholokhov, The study of the morphogenesis of flower buds in connection with variety testing and selection of stone fruits for winter hardiness: guidelines, 13 (1972)

B. A. Dospekhov, Methods of field experience, 5th ed., 351 (Agropromizdat, 1985)

12. V. N. Yezhov, A. V. Smykov, V. K. Smykov, S. Yu. Khokhlov, HortScience, 40(1), 5 (2005)

13. G. Šurlan-Momirović, M. Milutinivić, V. Rakonjac, N. Ralević, I. Ralević, D. Nikolić, Acta Hort, 484, 123 (1999) https://actahort.org/

14. O.V. Eremina, Scientific works of SKFNCSVV, 25, 59 (2019)

15. A. A. Yushev, I. G. Chukhina, Collection of genetic resources of fruit and berry plants: conservation, replenishment, study, Methodological guidelines (2016)

16. L. A. Lukicheva, L. A. Chernen'kiy, Biological and economic peculiarities of cherry, varieties introduced to Crimea, Fruit and berry growing in Russia (2019)

17. Yu. Pluhatar, Catalog of featured collections of fruit crops of the Nikitsky Botanical Garden. (Simferopol) (2018)

18. E. Chitu, Phenological and climatic simulation of the late frost damage in plum orchard under the climate conditions of Romania, 803, 139 (ActaHorticulturae, 2008) 
19. L. A. Lukicheva, L. A. Chernenky, A. O. Skripka, Proceedings of KubSAU, 4(85), 124 (2020)

20. M. Brüggenwirth, M. Knoche, Journal of the American Society for Horticultural Science, 141(2), 162 (2016) https://journals.ashs.org

21. L. A. Lukicheva, V. M. Gorina, Zh. S. Sokolovskaya, J. Fruit and berry growing in Russia, 54, 165 (2018)

22. I. M. Shaitan, L .M. Chuprina, V. A. Anpilogova, Biological features and cultivation of peach, apricot, cherry plum, 256 (1989)

23. 26. V. M. Gorina, L. A. Lukicheva, Bull. of the State Nikita Botan. Gard, 132, 67 (2019)

24. 27. V. M.Gorina, L. A. Lukicheva, Izvestiya Orenburg state Agrarian University, 1(57), 148 (2016) 